\title{
STRATEGI PENGEMBANGAN SISTEM AGRIBISNIS KELAPA SAWIT (Elaeis Guineensis Jacq) DI KABUPATEN LABUHAN BATU UTARA
}

\author{
Bambang Hermanto, Sri Wahyuni \\ Universitas Muslim Nusantara Al Washliyah Medan \\ Email :bambanghermanto@umnaw.ac.id
}

The purpose of this research is to find out what are the strengths, weaknesses, opportunities, and threats in the strategy of developing an oil palm agribusiness system (Elaeis Guineensis Jacq) in North Labuhan Batu Regency. The sampling research method used is purposive sampling method. The data used are primary data and secondary data. The analytical method used is descriptive quantitative method using SWOT analysis by analyzing the IFAS (Internal Factor Analysis Summary) and EFAS (External Factor Analysis Summary) factors. The results showed that using the SWOT diagram matrix, the oil palm agribusiness system development strategy was found in area II (Diversification Strategy). The situation in area II is a situation where farmers have to change their previous strategy, because the development of oil palm faces various threats but oil palm farmers still have internal strength. The focus of the strategy is to take action using strengths to take advantage of long-term opportunities by means of product and market diversification strategies.

\section{Keywords: Development strategy, Agribusiness System}

Tujuan penelitian adalah untuk mengetahui apa yang menjadi kekuatan, kelemahan, peluang, dan ancaman pada strategi pengembangan sistem agribisnis kelapa sawit (Elaeis Guineensis Jacq) di Kabupaten Labuhan Batu Utara. Metode penelitian pengambilan sampel yang digunakan adalah metode purposive sampling. Data yang digunakan data primer dan data sekunder. Metode analisis yang digunakan adalah metode deskriptif kuantitatif dengan menggunakan analisis SWOT dengan menganalisis faktor IFAS (Internal Factor Anlysis Summary) dan faktor EFAS (External Factor Analysis Summary). Hasil penelitian menunjukkan bahwa mengguna kan matriks diagram SWOT diperoleh strategi pengembangan sistem agribisnis kelapa sawit berada pada daerah II (Strategi Diversifikasi). Situasi pada daerah II merupakan situasi petani harus mengubah strategi yang sebelumnya, dikarenakan pengembangan kelapa sawit tersebut menghadapi berbagai ancaman namun petani kelapa sawit masih memiliki kekuatan dari segi internal. Fokus strategi yaitu melakukan tindakan menggunakan kekuatan untuk memanfaatkan peluang jangka panjang dengan cara stategi diversisifikasi produk dan juga pasar.

\section{Kata Kunci : Strategi pengembangan, Sistem Agribisnis}




\section{PENDAHULUAN}

Indonesia sebagai negara agraris memiliki sumberdaya alam yang baik. Hal ini menjadikan subsektor perkebunan Indonesia menjadi berkembang dan memiliki keterkaitan secara langsung dengan aspek pemberdayaan petani. Dalam aspek pemberdayaan ekonomi petani, subsektor perkebunan berperan sebagai sumber devisa negara, sumber ekonomi wilayah serta sebagai sumber pendapatan masyarakat. Cara yang paling efektif dan efisien untuk memberdayakan ekonomi petani adalah dengan mengembangkan sektor agribisnis (Syahza, 2004). Perkebunan kelapa sawit merupakan bagian penting dari system pendapatan keuangan masyarakat guna kelancaran kegiatan perekonomian suatu masyarakat. Perkebunan kelapa sawit merupakan alternatif bagi masyarakat dalam memlilih pekerjaan yang sesuai dengan dasar kemampuan masyarakat. Perkebunan kelapa sawit juga terbukti dapat bertahan dalam kondisi krisis ekonomi Indonesia dalam akhir dekade lalu, dan sebagai alternatif terhadap sistem kapitalis dan sistem sosialis. (Buchari, Alma, 2004)

Sistem agribisnis merupakan suatu tatanan yang didukung oleh seperangkat subsistem yang saling terkait, yaitu : (1) subsistem pengadaan dan penyaluran sarana produksi, teknologi dan pengembangan sumber daya pertanian, (2) susbsistem produksi dan usahatani, (3) subsistem pengolahan hasil-hasil atau agribisnis dan (4) subsistem pemasaran hasilhasil pertanian ( Abdul Adjid,1998).
Pertanian modern berwawasan agribisnis pada dasarnya merupakan wujud pertanian yang menjadi ciri pada era global. Strategi pengembangan industri pertanian yang dikembangkan di pedesaan. Oleh karena itu, sistem agribisnis sebagai suatu arah pembangunan pertanian merupakan suatu upaya penting untuk mencapai berbagai tujuan antara lain : (1) mendorong sektor pertanian, (2) menciptakan struktur pertanian yang tangguh, menciptakan nilai tambah, (4) meningkatkan penerimaan devisa, (5) menciptakan lapangan kerja, dan (6) memperbaiki distribusi pendapatan.

Kabupaten Labuhan Batu Utara merupakan salah satu sentra produksi kelapa sawit di Provinsi Sumatera Utara, untuk itu perlu dikembangkan sistem agribisnis kelapa sawit di Kabupaten Labuhan Batu Utara, berdasarkan luas areal tanaman kelapa sawit dari masingmasing kecamatan yang ada di Kabupaten Labuhan Batu diperoleh data dari Badan Pusat Statistik Labuhan Batu Utara yaitu sebagai berikut : 
Tabel 1. Luas Areal Kelapa Sawit Menurut Kecamatan di Kabupaten Labuhan Batu Utara

\begin{tabular}{|c|c|c|c|c|c|}
\hline \multirow{2}{*}{ Kecamatan } & \multicolumn{5}{|c|}{ Luas Tanaman (Ha) } \\
\hline & TBM & $\mathrm{TM}$ & TTM & Jumlah & Produksi \\
\hline (1) & (2) & (3) & (4) & (5) & (6) \\
\hline NA IX-X & 975 & 7629 & 380 & 8984 & 119012,40 \\
\hline Marbau & 1191,52 & 8738 & 51 & 9980 & 136312,80 \\
\hline Aek Kuo & 494 & 8281 & 25 & 8800 & 129183,60 \\
\hline Aek Natas & 579 & 12951 & 17 & 13547 & 202035,60 \\
\hline Kualuh Selatan & 363,78 & 6920 & 43 & 7326,78 & 107952 \\
\hline Kualuh Hilir & 2836,34 & 2476 & 41 & 5353,34 & 38625,60 \\
\hline Kualuh Hulu & 3230,18 & 13004 & 56 & 16290,18 & 202862,40 \\
\hline Kualuh Leidong & 1930,77 & 2233 & 38 & 4201,77 & 34834,80 \\
\hline 2018 & 11600,59 & 62232 & 651 & 74483,59 & 970819,20 \\
\hline 2017 & 4345 & 59634 & 517 & 64496 & \\
\hline
\end{tabular}

Sumber : Kabupaten Labuhan Batu Utara Dalam Angka 2019

Menurut Juch dan Glueck (1997) strategi adalah rencana yang di satukan, komperhensif dan terpadu yang menghubungkan ke unggulan srategi (strategi advantage) petani dengan tantangan lingkungan dan yang di rancang untuk memastikan bahwa sasaran dari petani kan di capai dengan pelaksanaan yang tepat oleh organisasi.

Strategi adalah rencana bersekala besar yang berorontas jangakaun masa depan yang jauh serta di tetapkan sedemikian rupa sehingga memungkinkan organisasi berinteraksi secara aktif dengan lingkungannya dalam kondisi persaingan yang semua di arahkan pada optimalisasi pencapain tujuan dengan berbagai sasaran yang bersangkutan.

Subsistem agribisnis hulu (upstream agribusiness) yang merupakan kegiatan ekonomi yang menyediakan sarana produksi bagi pertanian, seperti industri dan perdagangan agrokimia (pupuk, pestisida, dll), industri agrootomotif (mesin dan peralatan), dan industri benih/bibit. Subsistem usahatani (onfarm agribusiness) yang merupakan kegiatan ekonomi yang menggunakan sarana produksi yang dihasilkan oleh subsistem agribisnis hulu untuk menghasilkan produk pertanian primer. Termasuk ke dalam subsistem usahatani ini adalah usaha tanaman pangan, usaha tanaman hortikultura, usaha tanaman obatobatan, usaha perkebunan, usaha perikanan, usaha peternakan, dan kehutanan.

Subsistem agibisnis hilir (down-stream agribusiness) yang berupa kegiatan ekonomi yang mengolah produk pertanian primer menjadi produk olahan, baik produk antara maupun produk akhir, beserta kegiatan perdagangan di pasar domestik maupun di pasar internasional. Kegiatan ekonomi yang termasuk dalam subsistem agibisnis hilir ini antara lain adalah industri pengolahan makanan, industri pengolahan minuman, industri pengolahan serat (kayu, kulit, karet, sutera, jerami), industri jasa boga, industri farmasi dan bahan kecantikan, dan lain-lain beserta 
kegiatan perdagangannya.

Disamping ketiga subsistem di atas, diperlukan subsistem keempat sebagai bagian dari pembangunan sistem agribisnis. Subsistem penunjang adalah seluruh kegiatan yang menyediakan jasa bagi agribisnis, seperti lembagakeuangan, lembaga penelitian dan pengembangan, lembaga transportasi, lembaga pendidikan, dan lembaga pemerintah.

Tanaman kelapa sawit (Elaeis Guineensis Jacq.) berasal dari Afrika Barat. Tetapi ada sebagian berpendapat justru menyatakan bahwa kelapa sawit berasal dari kawasan Amerika Selatan yaitu Brazil. Hal ini karena spesies kelapa sawit banyak ditemukan di daerah hutan Brazil dibandingkan Amerika. Pada kenyatannya tanaman kelapa sawit hidup subur di luar daerah asalnya, seperti malaysia, Indonesia, Thailand, dan Papua Nugini. Bahkan, mampu memberikan hasil produksi perhektar yang lebih tinggi (Fauzi et $a l,$. 2012).

SWOT adalah singkatan dari lingkungan internal Strengths dan Weaknesses serta lingkungan eksternal Opportunities dan Threats yang dihadapi dunia bisnis. Analisis SWOT membandingkan antara faktor eksternal peluang (opportunities) ancaman (threats) dengan faktor internal Kekuatan (strengths), dan Kelemahan (weaknesses). Dalam penyusunan perencanaan strategis disususun melalui 3 tahap analisis yaitu: Tahap Pengumpulan Data, Tahap Analisis, dan Tahap pengambilan keputusan.

Pada tahap pengumpulan data, data dapat dibedakan menjadi dua yaitu: Data Eksternal dan Data Internal. Sedangkan untuk model, model yang dipakai pada tahap ini terdiri atas: Matriks Faktor Strategi Eksternal, Matriks Strategi Internal dan Matriks posisi (Rangkuti, 2013).

\section{Matriks Faktor Strategi Internal}

Setelah faktor - faktor strategi internal suatu petani diidentifikasi, suatu tabel IFAS (Internal Strategi Factors Analysis Summary) disusun untuk merumuskan faktor - faktor strategis internal tersebut ke dalam kerangka Kekuatan dan Kelemahan petani. Berikut adalah cara penentuan Faktor Strategi Internal:

1. Susunlah dalam kolom 1 faktor faktor internal Peluang dan Ancaman.

2. Beri bobot masing - masing faktor dalam kolom 2 sesuai dengan besar kecilnya pengaruh yang ada pada faktor strategi, mulai dari nilai 4 (Sangat Penting), nilai 3 (Penting), nilai 2 (Cukup Penting), dan nilai 1 (Sangat tidak Penting).

3. Hitung rating (dalam kolom 3) untuk masing - masing faktor dengan memberikan skala mulai dari 0 sampai dengan 1 berdasarkan pengaruh faktor tersebut terhadap kondisi petani.

4. Kalikan bobot pada kolom 2 dengan rating pada kolom 3, untuk memperoleh faktor pembobotan dalam kolom 4.

5. Jumlahkan skor pembobotan pada kolom 4, untuk memperoleh total skor pembobotan bagi petani yang bersangkutan. Nilai total ini menunjukkan bagaimana petani tertentu bereaksi terhadap faktorfaktor strategi eksternalnya (Rangkuti, 2013).

\section{Matriks Posisi}

Hasil analisis pada tabel matriks faktor strategi internal dan faktor strategi eksternal dipetakan pada matriks posisi dengan cara sebagai berikut : 
1. Sumbu horizontal (X) menunjukkan kekuatan dan kelemahan, sedangkan sumbu vertikal (Y) menunjukkan peluang dan ancaman.

2. Posisi petani ditentukan dengan hasil sebagai berikut :

- Kalau peluang lebih besar daripada ancaman maka nilai $Y>0$ dan
- Kalau ancaman lebih besar daripada peluang maka nilainya $\mathrm{Y}<0$.

- Kalau kekuatan lebih besar daripada kelemahan maka nilai $X>0$ dan

- Kalau kelemahan lebih besar daripada kekuatan maka nilainya $\mathrm{X}<0$.

\section{DIAGRAM ANALISIS SWOT}

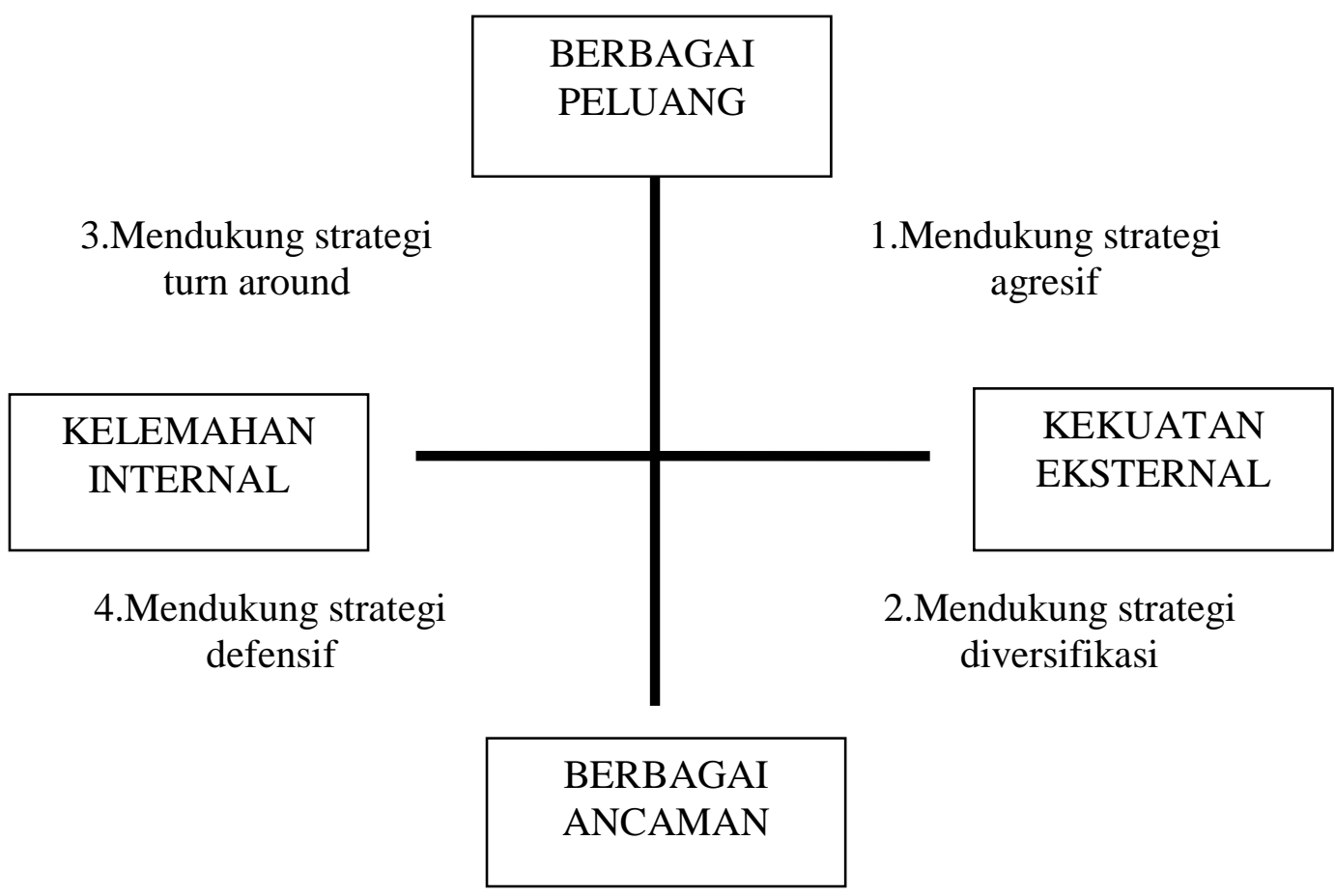

Gambar 1. Diagram Analisis SWOT

- Kuadran 1 : Merupakan situasi yang sangat menguntungkan. Petani tersebut memiliki peluang dan kekuatan sehingga dapat memanfaatkan peluang yang ada. Strategi yang harus diterapkan dalam kondisi ini adalah mendukung kebijakan pertumbuhan yang agresif (growth oriented strategy).

- Kuadran 2 : Meskipun menghadapi berbagai ancaman, petani ini masih memiliki kekuatan dari segi internal. Strategi yang harus diterapkan adalah menggunakan kekuatan untuk memanfaatkan peluang jangka panjang dengan cara strategi diversifikasi (produk/pasar).

- Kuadran 3 : Petani menghadapi peluang pasar yang sangat besar, tetapi di lain pihak, ia menghadapi beberapa kendala/kelemahan internal.

- Kuadran 4 : Ini merupakan situasi yang sangat tidak 
menguntungkan, petani tersebut menghadapi berbagai ancaman dan kelemahan internal (Rangkuti, 2013).

Matriks SWOT dapat menghasilkan empat set kemungkinan alternative srategis yaitu:

1. Strategi SO yaitu strategi ini dibuat berdasarkan jalan pikiran petani, yaitu dengan memanfaatkan seluruh kekuatan untuk merebut dan memanfaatkan peluang sebesar besarnya.
2. Strategi ST yaitu strategi ini adalah strategi dalam menggunakan kekuatan yang dimiliki petani untuk mengatasi ancaman..

3. Strategi WO yaitu strategi ini diterapkan berdasarkan pemanfaatan peluang yang ada dengan cara meminimalkan kelemahan yang ada.

4. Strategi WT yaitu strategi ini didasarkan pada kegiatan yang meminimalkan kelemahan yang ada serta menghindari ancaman.

Tabel 2. Matriks Analisis SWOT

\begin{tabular}{|c|l|l|}
\hline IFAS & \multicolumn{1}{|c|}{$\begin{array}{c}\text { Kekuatan } \\
\text { (strengthts) }\end{array}$} & \multicolumn{1}{|c|}{$\begin{array}{c}\text { Kelemahan } \\
\text { (Weakness) }\end{array}$} \\
\hline $\begin{array}{c}\text { Peluang } \\
\text { (oppurtunities) }\end{array}$ & $\begin{array}{l}\text { Strategi S-O } \\
\text { Ciptakan strategi yang } \\
\text { menggunakan kekuatan } \\
\text { untuk memanfaatkan } \\
\text { peluang Strategi S-T }\end{array}$ & $\begin{array}{l}\text { Strategi W-O } \\
\text { Ciptakan strategi yang } \\
\text { meminimalkan } \\
\text { kelemahan untuk } \\
\text { memanfaatkan peluang }\end{array}$ \\
\hline $\begin{array}{c}\text { Ancaman } \\
\text { (threats) }\end{array}$ & $\begin{array}{l}\text { Ciptakan strategi yang } \\
\text { menggunakan kekuatan } \\
\text { untuk mengatasi ancaman }\end{array}$ & $\begin{array}{l}\text { Siptakan strategi yang } \\
\text { meminimalkan } \\
\text { kelemahan dan } \\
\text { menghindari ancaman }\end{array}$ \\
\hline
\end{tabular}

Sumber : Rangkuti, 2013

\section{METODE PENELITIAN}

\section{Lokasi dan Waktu Penelitian}

Penelitian ini dilaksanakan di

Kabupaten Labuhan Batu Utara, Provinsi Sumatera Utara. Daerah penelitian ditetapkan secara purposive (sengaja) yaitu berdasarkan pertimbanganpertimbangan tertentu disesuaikan dengan tujuan penelitian (Singarimbun, 1989). Lama penelitian dilakukan selama tiga bulan yaitu pada bulan Juni-Agustus tahun 2020. Adapun yang menjadi pertimbangan ialah karena Kabupaten Labuhan Batu merupakan salah satu daerah penghasil sawit terbesar di Provinsi Sumatera Utara. Penelitian ini dilaksanakan selama tiga bulan, yaitu pada bulan Juni sampai dengan Agustus 2020.

Metode dan analisis data bertujuan untuk menyerderhanakan seluruh data yang terkumpul, menyajikan secara sistematik, kemudian mengolah, menafsirkan, dan memaknai data tersebut. Analisis data merupakan upaya pemecahan 
permasalahan penelitian untuk memperoleh jawaban atas permasalahan yang diteliti. Permasalahan dalam penelitian ini akan dianalisis secara deskriptif kuantitatif, deskriptif kualitatif, analisis IFAS (Internal Factors Analysis Summary) dan EFAS (External Factors Analysis Summary) serta analisis SWOT (Strengths, Weaknesses, Opportunities, Threats) untuk merancang strategi pengembangannya. Dengan keempat alat analisis tersebut diharapkan akan dapat memecahkan permasalahan yang akan diteliti

\section{HASIL DAN PEMBAHASAN}

Adapun tabel perhitungan pembobotan dikali rating faktor internal strategi pengembangan sistem agribisnis kelapa sawit di Kabupaten Labuhan Batu Utara dapat disajikan pada Tabel 3 berikut ini :

Tabel 3. Matriks Evaluasi Faktor Internal Strategi Pengembangan Sistem Agribisnis Kelapa Sawit di Kabupaten Labuhan Batu Utara

\begin{tabular}{lccc}
\hline Faktor strategis (kekuatan) & Rating & Bobot & Skor \\
\hline Ketersediaan benih bibit & 4 & 0.23 & 0.94 \\
Ketersediaan tenaga kerja & 3 & 0.17 & 0.52 \\
Ketersediaan lahan & 3 & 0.17 & 0.52 \\
\hline Faktor strategis (kelemahan) & Rating & Bobot & Skor \\
\hline Kurangnya modal & 3 & 0.17 & 0.52 \\
Kurangnya teknologi & 2 & 0.11 & 0.23 \\
Kurangnya bantuan pemerintah & 2 & 0.11 & 0.23 \\
\hline
\end{tabular}

Sumber : Analisis Data Primer, 2020

Adapun tabel perhitungan pembobotan dikali rating faktor eksternal strategi pengembangan sistem agribisnis kelapa sawit di
Kabupaten Labuhan Batu Utara dapat disajikan pada Tabel 4 berikut ini : 
ketersediaan bibit kelapa sawit, ketersediaan tenaga kerja, ketersediaan lahan, kurangnya modal usaha, reandahnya penguasaan teknologi, kurangnya bantuan pemerintah, Faktor yang paling tinggi ratingnya adalah ketersediaan bibit kelapa sawit. Ada 4 faktorfaktor eksternal dalam pengembangan kelapa sawit yaitu tersedianya informasi pasar, harga kelapa sawit yang stabil, keterbatasan penyuluhan, kurangnya sarana dan prasarana dimana faktor yang paling tinggi ratingnya adalah tenaga penyuluh.

Setelah melakukan perhitungan bobot dari masing-masing faktor internal maupun eksternal kemudian dianalisis dengan menggunakan matrik posisi. Matrik ini digunakan untuk melihat posisi strategi pengembangan sistem agribisnis kelapa sawit di Kabupaten Labuhan Batu Utara berdasarkan Tabel 5 diperoleh nilai $\mathrm{X}>0$ yaitu 1 dan nilai $\mathrm{Y}<0$ yaitu -1 . Posisi titik kordinatnya dapat dilihat pada kordinat Cartesius berikut ini :

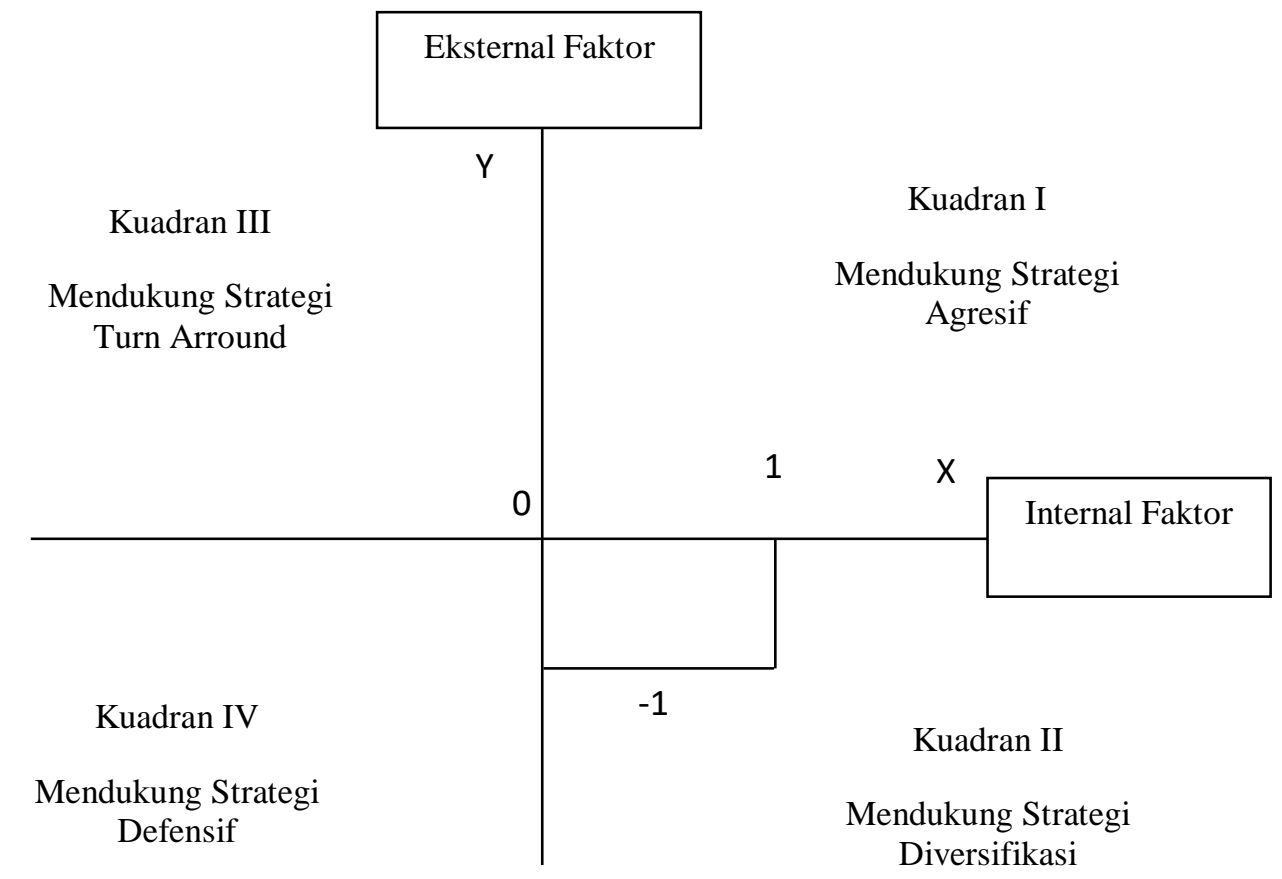

\section{Gambar 4. Matriks SWOT Pengembangan Usahatani Kelapa sawit Arabika}

Dari hasil hasil matriks internal - eksternal yang diperoleh dari nilai total skor pembobotan pada strategi pengembangan diperoleh faktor internal bernilai 1 yang artinya nilai ini merupakan selisih antara kekuatan dan kelemahan, dimana kekuatan lebih besar dibandingkan dengan kelemahan. Dan untuk faktor eksternal, bernilai -1 yang artinya nilai ini merupakan selisih antara peluang dan ancaman, dimana nilai ancaman lebih besar dari peluang.

Dari diagram diperoleh usaha srategi pengembangan usaha tani kelapa sawit berada pada daerah II (Strategi Diversifikasi). Situasi pada daerah II merupakan situasi petani harus mengubah strategi yang sebelumnya, dikarenakan pengembangan kelapa sawit tersebut menghadapi berbagai ancaman 
namun petani kelapa sawit masih memiliki kekuatan dari segi internal. Fokus strategi yaitu melakukan tindakan menggunakan kekuatan untuk memanfaatkan peluang jangka panjang dengan cara stategi diversisifikasi produk dan juga pasar. Strategi ST bertujuan untuk menggunakan kekuatan yang dimiliki petani untuk mengatasi ancaman.
Penjelasan hasil di atas dari tahap pengumpulan data, data diperoleh lagi yang lebih spesifik, dengan membuat "Tahap Analisis", dimana memanfaatkan semua informasi kedalam model perumusan strategi. Model tersebut adalah matriks SWOT, sehingga beberapa katagori yang muncul yakni strategi SO, strategi ST, strategi WO, strategi WT dapat diperoleh. Matriks SWOT dapat dilihat pada Tabel 6 berikut :

Tabel 6. Matriks SWOT Strategi Pengembangan Sistem Agribisnis Kelapa Sawit di Kabupaten Labuhan Batu Utara

\begin{tabular}{|c|c|c|}
\hline EFAS & $\begin{array}{l}\text { Kekuatas }(\mathrm{S}) \\
\text { 1. Ketersediaan bibit kelapa sawit } \\
\text { 2. Ketersediaan tenaga kerja } \\
\text { 3. Ketersediaan lahan }\end{array}$ & $\begin{array}{l}\text { Kelemahan }(\mathrm{W}) \\
\text { 1. Modal usahatani } \\
\text { 2. Penguasaan teknologi } \\
\text { 3. } \text { Bantuan pemerintah }\end{array}$ \\
\hline $\begin{array}{l}\text { Peluang }(\mathrm{O}) \\
\text { 1. Informasi pasar yang } \\
\text { tersedia } \\
\text { 2. Harga kelapa sawit } \\
\text { yang stabil }\end{array}$ & $\begin{array}{l}\text { STRATEGI SO } \\
\text { a. Mengembangkan produksi } \\
\text { usaha kelapa sawit dengan } \\
\text { bibit kelapa sawit berkualitas } \\
\text { berdasarkan imnformasi yang } \\
\text { ada (S1,O1) } \\
\text { b. Penyediaan suplai produksi } \\
\text { kelapa sawit mengembangkan } \\
\text { sumber daya lokal yang } \\
\text { dilakukan lahan } \\
\text { pengembangan tingginya } \\
\text { usahatani akibat } \\
\text { harga kelapa sawit (S1, S3, } \\
\text { O2) melalui } \\
\text { Usaha-usaha meningkatkan } \\
\text { pendapatan masyarakat } \\
\text { melalui pengembangan bisnis } \\
\text { kelapa sawit (S2, S3, O2) }\end{array}$ & $\begin{array}{l}\text { STRATEGI WO } \\
\text { a. Pemberdayaan lemabaga } \\
\text { keuangan yang efektif } \\
\text { terhadap pengembangan } \\
\text { usaha kelapa sawit (S1, } \\
\text { W1) } \\
\text { b. Pengadaan pelatihan } \\
\text { penggunaa modal usaha } \\
\text { kelapa sawit untuk tujuan } \\
\text { yang lebih efektif (W1, } \\
\text { S1, S2) bantuan } \\
\text { Meningkatkan bana } \\
\text { pemerintah pada usaha } \\
\text { kelapa sawit setelah } \\
\text { adanya peningkatan harga } \\
\text { jual kelapa sawit yang } \\
\text { tinggi sehingga } \\
\text { pengembangan bisnis } \\
\text { kelpa sawit berjalan } \\
\text { dengan cepat (W3, S2) }\end{array}$ \\
\hline $\begin{array}{l}\text { 1. Tenaga penyuluh } \\
\text { 2. Sarana dan prasarana }\end{array}$ & \begin{tabular}{|lr} 
a. & $\begin{array}{l}\text { Penyuluhan beragam dan } \\
\text { seimbang }\end{array}$ \\
mengupayakan & yang \\
pengembangan & \\
kelapa sawit rahatani \\
teknologi yang
\end{tabular} & 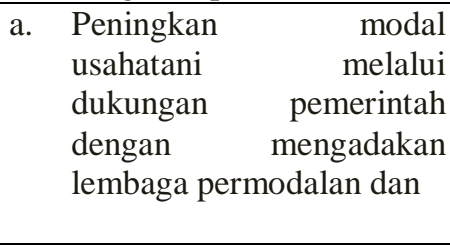 \\
\hline
\end{tabular}




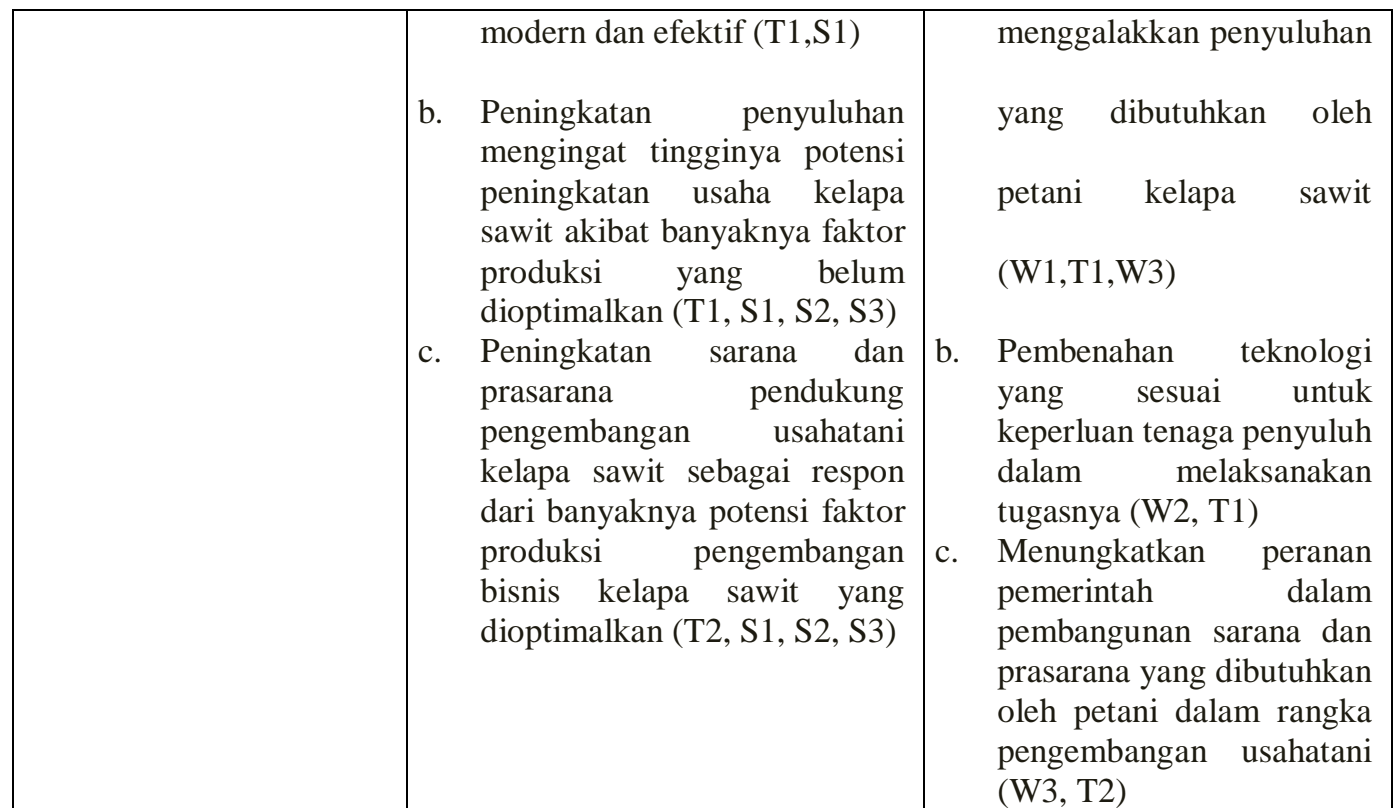

Sumber : Data diolah peneliti, 2020

\section{Pada "Tahap Pengambilan} Keputusan" berdasarkan hasil pencocokan dari matriks SWOT strategi pengembangan sistem agribisnis kelapa sawit di Kabupaten Labuhan Batu Utara diperoleh beberapa alternatif strategi yang dilakukan dalam pengembangan usaha kelapa sawit seperti berikut :

1. Strategi SO

a. Mengembangkan produksi usaha kelapa sawit dengan bibit kelapa sawit berkualitas berdasarkan informasi yang ada. (S1,01)

b. Penyediaan suplai produksi kelapa sawit mengembangkan sumberdaya lokal, yang dilakukan melalui pengembangan lahan usaha tani akibat tingginya harga kelapa sawit (S1,S3, O2).

c. Usaha-usaha meningkatkan pendapatan masyarakat melalui pengembangan bisnis kelapa sawit (S2,S3, O2).

2. Strategi ST

a. Penyuluhan beragam dan seimbang yang mengupayakan pengembangan usaha kelapa sawit berbasis teknologi yang modern dan efektif. $(\mathrm{T} 1, \mathrm{~S} 1)$ b. Peningkatan frekuensi penyuluhan mengingat tingginya potensi peningkatan usahatani kelapa sawit akibat banyaknya faktor produksi yang belum dioptimalkan. (T1,S1,S2,S3)

c. Peningkatan sarana dan prasarana pendukung pengembangan usahatani kelapa sawit sebagai respon dari banyaknya potensi faktor produski pengembangan bisnis kelapa sawit yang dioptimalkan. (T2,S1,S2,S3)

3. Strategi WO

a. Pemberdayaan lembaga keuangan yang efektif terhadap pengembangan usaha kelapa sawit $(\mathrm{S} 1, \mathrm{~W} 1)$

b. Pengadaan pelatihan penggunaan modal usaha kelapa sawit untuk tujuan yang lebih efektif (W1,S1,S2).

c. Meningkatkan bantuan pemerintah pada usaha kelapa sawit setelah adanya peningkatan harga jual kelapa sawit yang tinggi sehingga pengembangan bisnis kelapa sawit berjalan dengan cepat. (W3,S2)

4. Strategi WT

a. Peningkatan modal usaha tani melalui dukungan pemerintah dengan mengadakan lembaga permodalan dan menggalakkan 
kegiatan penyuluhan yang dibutuhkan oleh petani kelapa sawit (W1, T1, W3)

b. Pembenahan teknologi yang sesuai untuk keperluan tenaga penyuluh dalam melaksanakan tugasnya. (W2,T1)

\section{KESIMPULAN}

1. Ada 6 faktor-faktor internal dalam strategi pengembangan sistem agribisnis kelapa sawit yaitu ketersediaan bibit kelapa sawit, ketersediaan tenaga kerja, ketersediaan lahan, kurangnya modal usaha tani, rendahnya penguasaan teknologi, kurangnya bantuan pemerintah. Faktor yang palingAbAdul Adjid,1998. Sistem Agribisnis tinggi ratingnya adalah ketersediaan bibit kelapa sawit. Ada 4 faktorfaktor eksternal dalam pengembangan sistem agribsnisAdiA.P., 2011. Kaya Dengan Bertani

kelapa sawit yaitu tersedianya Kelapa Sawit. Pustaka Baru informasi pasar, harga kelapa sawit yang stabil, keterbatasan penyuluhan,Al Buchari, 2004, Manajemen Pemasaran kurangnya sarana dan prasarana dimana faktor yang paling tinggi ratingnya adalah keterbatasan tenagaAri Into, S. 2010. Prosedur Penelitian : penyuluh.

2. Posisi usaha kelapa sawit dalam matriks posisi SWOT terletak padaBa Ian Agribisnis. 1995. Sistem, Strategi kuadran II $(1 ;-1)$ sehingga alternatif strategi pengembangan yang dianjurkan adalah strategi diversifikasi (Diversifikation strategic) yaitu dengan meningkatkan sarana dan prasarana pendukung pengembangan usaha kelapa sawit sebagai respon dari banyaknya potensi faktor produksi pengembangan bisnis usaha kelapaGluJauch. 1997. Manajemen Strategis dan sawit yang dioptimalkan serta Kebijakan Perusahaan. Edisi Ketiga. menggalakkan kegiatan penyuluhan yang dibutuhkan oleh petani kelapa sawit mengupayakan usahataniKur Miawan, 2007. Biaya Investasi Industri berbasis teknologi serta peningkatan frekuensi penyuluh. c. Meningkatkan peranan pemerintah dalam pembangunan sarana dan prasarana yang dibutuhkanoleh petani dalam rangka pengembangan usahatani (W3, T2)

\section{DAFTAR PUSTAKA}

Swadaya Kelapa Sawit Dalam Mengelola Perkebunan Kelapa Sawit di Desa Sungai Kupang Jaya Kecamatan Kelumpang Selatan Kabupaten Kotabaru. Jurnal Pendidikan Geografi . Vol 2. No 2. E-ISSN 2356-5225. Terintegrasi Hulu-Hilir. Muara Indah. Bandung.

Press. Yogyakarta. dan Pemasaran Jasa, Cetakan Keenam, Alfabeta, Bandung. Suatu Pendekatan Praktik. Jakarta : Rineka Cipta.

dan Program Pengembangan Agribisnis. Departemen Pertanian. Jakarta.

Badan Pusat Statistik. Kabupaten Labuhan Batu Utara Dalam Angka 2019

Fauzi, Y. , 2012. Kelapa Sawit. Edisi Revisi. Penebar Swadanya. Jakarta Terjemahan Murad dan Henry. Erlangga. Jakarta. (Anoraga, 2004) Kelapa Sawit, dalam Potensi dan Peluang Investasi Industri Kelapa Sawit di Indonesia. Pusat Penelitian Kelapa Sawit, Medan, Indonesia. 
Jurnal Potensi

Program Studi Magister Perencanaan Wilayah Universitas Batam

Volume I, Issue 1, Maret 2021, Page 23-35

Masykur. 2013. Pengembangan Industri Kelapa Sawit Sebagai Penghasil Energi Bahan Bakar Alternatif dan Mengurangi Pemanasan Global (Studi di Riau Sebagai Penghasil Kelapa Sawit Terbesar di Indonesia. Jurnal Reformasi. Vol. 3. No.2

Pahan, I. , 2012. Kelapa Sawit Manajemen Agribisnis dan Hulu Hingga Hilir. Cetakan Pertama. Penebar Swadanya. Jakarta

Rangkuti, Freddy. 2009. Strategi Promosi Yang Kreatif \& Analisis Kasus Integrated Marketing Communication. Jakarta : PT Gramedia Pustaka Utama.

Rangkuti, Freddy. 2013. Analisis SWOT: Teknik Membedah Kasus Bisnis. Jakarta :PT. Gramedia Pustaka Utama.

ugiyanto. 2010. Model-model Pembelajran Inovatif. Surakarta : Yuma Pustaka.

Sugiyono. 2010. Metode Penelitian Kuantitatif Kualitatif \& RND. Bandung : Alfabeta.

Soekartawi. 2001. Analisis Usahatani. UI Press. Jakarta.

Supadi dan Nurmanaf, 2006. Pemberdayaan Petani Kelapa Dalam Upaya Peningkatan Pendapatan. Jurnal Litbang Pertanian. Pusat Analisis Sosial Ekonomi dan Kebijakan Pertanian. Bogor.

Syahza, 2004. Rancangan model pemberdayaan ekonomi masyarakat pedesaan berbasis agribisnis di daerah Riau, Jurnal Pembangunan Pedesaan 3 (2): 1-16.

Tim Bina Karya Tani. 2009. Pedoman Bertanam Kepala Sawit. Yrama Widya. Cetakan 1.

Triyono, D 2015. Strategi Pengembangan Kebun Kelapa Sawit Lahan Gambut Kabupaten Kubu Raya. Jurnal Sosial Ekonomi Pertanian. Vol 4 No. $2 \mathrm{Hlm}$ 40-48 